\title{
Foreign Direct Investments on Small Scale Industries in India
}

\author{
K. Praveenkumar, S. Josephin Arulmozhi, G. Vinayagamoorthi
}

\begin{abstract}
Foreign direct investment (FDI) in little scale industry (SSI) It could be exactly what the part needs. Indeed, the legislature's detailed move to change FDI here by moving the endorsement administration by maybe notwithstanding raising the business particular tops on remote value proprietorship could help India's prospects in the race to secure worldwide capital for its economy. India has allowed Foreign Direct Investment up to 100 percentages in many manufacturing industries which were designated as Small Scale Industries. Increased FDI inflows to a country can create several positive economic effects. Among others, FDI can affect labor and capital markets, trade patterns and economic growth. Indian SSI units would be eligible to raise foreign equity in accordance with caps governing the sectors in which they operate, thereby improving their access to technology and capital and assisting in the growth and modernization of the sector. For the past years big companies getting FDI is not difficult issue because of financial security, reach in global market and business experience but in SME/SSI it still very ease compared with big companies. But the same time SSIs sick units and startups are very low level in getting guidance for capital management like venture capital and attract the investments from the foreign countries. This study focused on the qualitative manner in SSIs capital management and problems related to attract the investments from the foreign countries .mainly make in India scheme gives more opportunities to small scale industries to equip their selves to global market through FDI. This study also analyze the make in India scheme's investment on SSIs in India.
\end{abstract}

Keywords : FDI, SSIs, SME, Startups, Venture Capital, Investments, Make In India.

\section{INTRODUCTION}

Small scale industries are important. It helps in rising employment and economic development of India. It improves the development of the country by increasing urban and rural growth. Role of Small and medium scale enterprises are to help the government in increasing infrastructures and manufacturing industries, reducing issues like pollution, slums, poverty, and many development acts. Small scale manufacturing industries and cottage industries play a very important role in the economic development of India. If any amount of capital is invested in

Revised Manuscript Received on October 15, 2019.

* Correspondence Author

K.Praveenkumar, Ph.D. Research Scholar, Dept. of Commerce, Alagappa University, Karaikudi, India.

S.Josephin Arulmozhi, Ph.D Research Scholar, Department of Commerce

Dr.G.Vinayagamoorthi, Assistant Professor, Dept. of Commerce, Alagappa University, Karaikudi, India , Alagappa University , Karaikudi, India

small scale industries it will help in reducing unemployment in India and increasing self-employment. The industry is a sector in which the production of goods is a segment of the economy. Let us learn more about the importance of Small scale industries and how SSI helps in developing the country. Small scale industries play an important role for the development of Indian economy in many ways. About 60 to 70 percent of the total innovations in India come from the SSIs. Many of the big businesses today were all started small and then nurtured into big businesses. "The SSI sector distinctly crucial in addressing the national objective of bridging the rural-urban divide, mitigate poverty and generating employment for the admirable community of the country. SSI sector comprises almost about $80 \%$ of the total industrial units in the country. In India, SSIs occupy 36 million units, contribute to $45 \%$ of industrial production, $40 \%$ to the export sector through more than 6000 products ranging from traditional to high-tech and provides employment to about 80 million persons". (Banik, Subhamoy. (2017).

Types of Small and medium scale enterprises For manufacturing enterprise, if the investment in plant and machinery (excluding land \& buildings) is within any of the following levels:

- Micro Enterprises: Investment of up to Rs.25 lakhs in plant and machinery

- Small Enterprises: Investment of up to Rs.5 crores in plant and machinery

- Medium Enterprises: Investment of up to Rs.10 crores in plant and machinery

For service enterprise, if the investment in plant and machinery (excluding land \& buildings) is within any of the following levels:

1. Micro Enterprises: Investment of up to Rs.10 lakhs in equipment

2. Small Enterprises: Investment of up to Rs.2 crores in equipment

3. Medium Enterprises: Investment of up to Rs.5 crores in equipment 
Importance of the SSIs in societal developments

1. Small Scale Industries Provides Employment

2. SSI Facilitates Women Growth Development

3. SSI Brings Balanced Regional

4. SSI Helps in Mobilization of Local Resources

5. SSI Paves for Optimisation of Capital

6. SSI Promotes Exports

7. SSI Complements Large Scale Industries

8. SSI Meets Consumer Demands

9. SSI Ensures Social Advantage

10. Develops Entrepreneurship

Main advantages of FDI in India

- Inflow of Foreign Capital- Capital base on domestic country increases

- Increase in tax revenue

- Boost economy in GDP growth

- Large employment opportunities

- Increase in international trade

- Increase in Forex reserves

\section{IMPORTANCE OF THE STUDY}

SSI's are the best examples for the Make in India initiative. They focus on the mission to manufacture in India and sell the products worldwide. This also helps create more demands from all over the world. India is the developing country, still India wants to emerge their selves to developed counties list even though India's recent activities related to industrial developments, economic reforms was shows its interest in devolvement of nation through modern industrial revolution. over the one third of percentage having the GDP from small scale industries but these industries affected by financial problem more the five years of 2009 to 2013. "Lack of capital, excessive dependence of agriculture and abundant supply of manpower are the characteristic futures of many developing countries in Asia. Happily these economies have been realizing that agriculture is which cannot meet their local requirements and therefore, that the pressure on land could be substantially reduced through the development of small scale industries". (G.Patil \& Dr.P.T.Chaudhari, 2014)

\section{OBJECTIVES OF THE STUDY}

- To analyze the FDI investments through make in India on SSIs in India

- To study the Indian SSIs capital management issues

\section{REVIEW OF LITERATURE}

Srinivas K T, (2013) has studied the performance of micro, small and medium enterprises and their contribution in India ${ }^{a e} s$ economic growth and concluded that MSMEs play a vital role in the inclusive growth of Indian economy Dr. Rashmi Sunil Dhobale (2015) investigates the advantages \& disadvantages of FDI in India.There are several benefits in investing in India viz., very bright future, and availability of cheap labour,availability of raw materials, sound infrastructure, and huge market availability. The drawbacks are inflationary pressure and monopolistic tendency by foreign companies affecting the domestic players. K. Narayanaswamy et.al (2016), in their study that "Make in India" initiatives will strengthen India's manufacturing sector. The movement has been concentrating to fulfil the purpose of job creation, enforcement to secondary and tertiary sector, boosting the national economy, converting India to a self-reliant country and to give the Indian economy global recognition.Capital is expressed as the motor of monetary development. Foreign direct investment (FDI) plays an unprecedented and developing part in worldwide business. It can furnish a firm with new markets and showcasing channels, less expensive generation offices, access to new innovation, items, abilities and financing(Basu, et. al., 2007).

Capital management problems of SSIs in India Capital management involved three types capital issues in small scale industries 1.seed capital 2.working capital and 3.venture capital

\section{Seed capital problems}

Adequate and timely supply of credit facilities is an important problem faced by small-scale industries. This is partly due to scarcity of capital and partly due to weak creditworthiness of the small units in the country.

\section{Working capital problems of SSIs}

"The SSIs has to decide about the sources of funds, which can be avail to make investment in the current assets. The problem of working capital management of small scale industries is not new, it is prevailing in India. The SSI units are low capital base where investment on fixed assets found to be less. Without the help of government support and financial institutions co-operation, it is very difficult to solve the problem of working capital management of SSIs of Rajasthan in particular and of India in general” (Matarneh, 2012) 


\section{Venture capital problems}

In Indian small and medium scale entrepreneurs, investors and manufactures are mainly affected the this issue because of after implementing of business in peak level, every business have certain percentage financial support for continues activity of business in India Venture Capital is emerging as an important source of finance for small and medium-sized firms, especially for starting the business and business expansion. The investment size-wise analysis of venture capital is also witnessing that 43 per cent of total financing is given within the size of less than \$1 million, which indicates significance of venture capital financing in small and medium sized enterprises.

The Role of Make In India in FDI on SSIs

FDI flows generally come as capital bundled with technology, skill and sometimes even market access. Larger inflows of foreign investments will support the economy to achieve a sustainable high path of economic growth. The promotion of SSI is essential in developing economies like India to achieve equitable distribution of income \& wealth, economic self-dependence \& entrepreneurial development. To empower the SSI sector to take its rightful place as the growth engine of Indian economy, it is necessary to support the MSMEs, educate and empower them to make optimum utilization of the resources, both human and economic, to achieve success. But in India before make in India scheme, SSIs affected by many problems including capital management, after that the make in India lanced the problems of SSIs related to capital handling is less than the before make in India and Mudhra loan scheme.

Figure 1: FDI equity inflows (2014-2019)

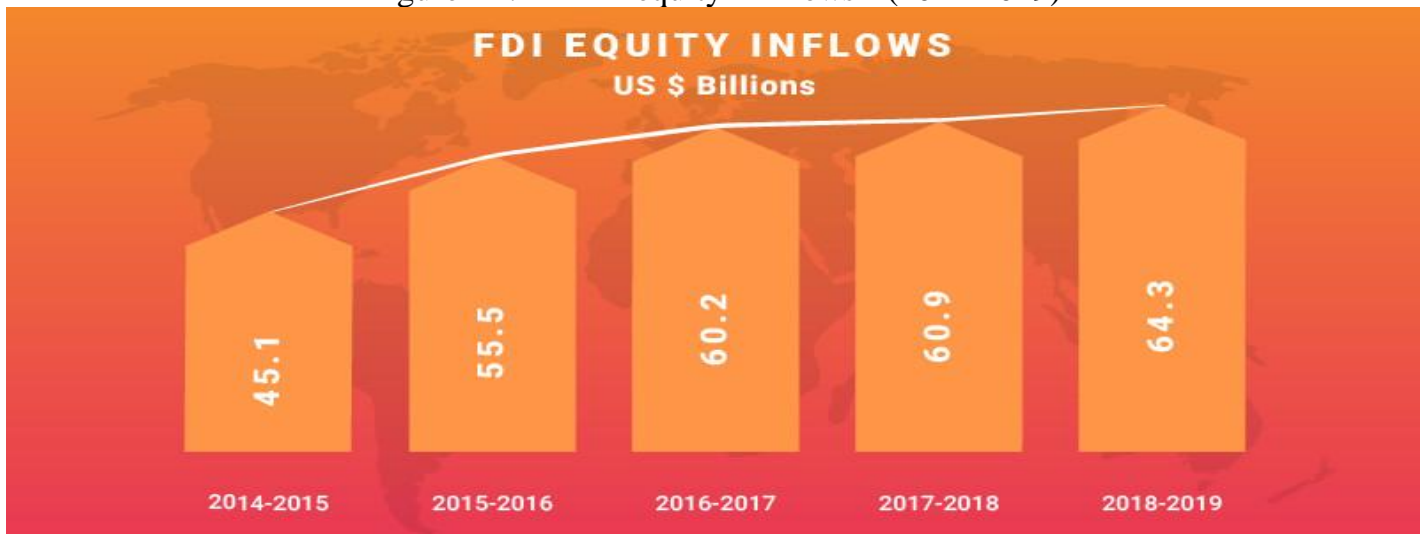

Source :www. make in india

Figure: 1 shows FDI in India has followed a positive trend since the launch of Make in India. FDI inflow from April 2014 to March 2019 (US\$ 286 bn) is 46.94\% (approx.) of the overall FDI received in the country since April 2000 (US\$ 592.08 bn). For the 1st time, India crossed the US\$ 60 bn mark in FY 2017 - 18 with US\$ 55.55 bn in FDI, due to the investment friendly policies and opening of FDI allowance in various sectors.

Table 1:Revenue Generated through Export by MSME sector (year wise )

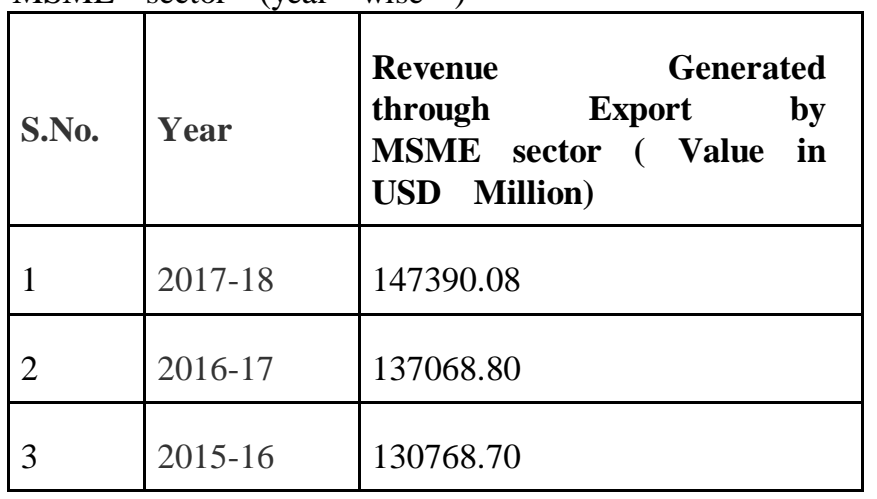

\begin{tabular}{|l|l|l|}
\hline 4 & $2014-15$ & 138896.72 \\
\hline 5 & $2013-14$ & 133313.28 \\
\hline 6 & $2012-13$ & 127992.76 \\
\hline
\end{tabular}

Source:https://pib.gov.in/Pressreleaseshare.aspx?PRID=156 3823

Table .1 shows the report of Revenue Generated through Export by MSME sector.The value of Micro Small and Medium Enterprises (MSME) related products exported during 2017-18 reached US\$ 124.4 bn as per data received from the Directorate General of Commercial Intelligence and Statistics (DGCIS). 
Table 2: Total Number of MSMEs registered on Udyog Aadhar Memorandum (UAM)

\begin{tabular}{|c|c|c|}
\hline Micro & Small & Medium \\
\hline $60,32,100$ & $7,28,516$ & 28,611 \\
\hline
\end{tabular}

Source : MSME press release

Table no.2 shows the report of total number of MSMEs registered on Udyog Aadhar memorandum it is implemented after that the mike in India scheme micro and small scale industries more numbers registered compared with medium industries.

Table 3: States with the highest number of MSMEs

\begin{tabular}{|l|c|}
\hline Maharashtra & $11,04,189$ \\
\hline Bihar & $8,29,694$ \\
\hline Tamil Nadu & $7,91,288$ \\
\hline Uttar Pradesh & $7,06,342$ \\
\hline Madhya Pradesh & $6,45,077$ \\
\hline
\end{tabular}

Source :www.udyogaadhaar.gov.in

SIDBI (Small Industries Development Bank of India)- Major funds managed by SIDBI:

- Fund of Funds for Startups: US\$ 1.43 bn available for contribution to various Alternative Investment Funds (AIFs)

- India Aspiration Fund: US\$ $286 \mathrm{mn}$ sector agnostic fund for startups

- ASPIRE Fund: US\$ $44.34 \mathrm{mn}$ available for funding agro-based start-ups

- Venture Capital Scheme - Small Farmers' Agri-Business Consortium (SFAC) has sanctioned venture capital assistance to 484 Projects amounting to US\$ $20.13 \mathrm{mn}$ having project cost of US\$ $233.30 \mathrm{mn}$ during January to December 2018.

- Multiplier Grants Scheme - US\$ $5.15 \mathrm{mn}$ support funds to reform R\&D of start-ups through industrial linkages.

- New Generation Innovation and Entrepreneurship Development Centre (IEDC) - Provides one-time, non-recurring financial assistance up to a maximum of US\$ 35,755 for knowledge-based and technology-driven start-ups.

- Aspire - A Scheme for Promotion of Innovation, Rural Industries and Entrepreneurship - was launched by Ministry of Micro, Small and Medium Enterprises. It aims to set up a network of technology centres and to set up incubation centres to accelerate entrepreneurship and to promote start-ups for innovation in agro-based industries.

\section{CONCLUSION}

FDI supplements and supplements local venture. The little and medium undertakings (SMEs) would be profited through FDI, by method for improved access to supplementary capital and cutting edge advancements, presentation to worldwide administrative practices and advances and additionally open doors for combination into worldwide market (Mohanty, 2018).thus this study clear overviwe about the FDI markets working condition and oppertunities in indian SSIs. A huge number of foreign direct investors stated that they were making profits in their current operations in India according to the FICCI survey.This study once again reveals the Make in india and FDI in SSIs both proves intiation of this schemes the good leads to future market sustainblity of Indian SSIs.

\section{REFERENCES}

1. https://www.toppr.com/guides/business-environment/scales-of-business/ro le-of-ssi-in-the economy/

2. https://accountlearning.com/important-role-small-scale-industries-indian-e conomy/

3. https://pib.gov.in/Pressreleaseshare.aspx?PRID $=1563823$

4. http://2.\%20https//udyogaadhaar.gov.in/UA/UAM_Registration.aspx

5. http://2.\%20https//udyogaadhaar.gov.in/UA/UAM_Registration.aspx

6. https://cleartax.in/s/small-scale-industries-ssi

7. https://www.pacprocess-india.com/en/Home/Partners

8. Banik, Subhamoy. (2017). SMALL SCALE INDUSTRIES IN INDIA: OPPORTUNITIES AND CHALLENGES. Volume 6, Issue 1 January 2018 ISSN: $2320-2882$ pp.337-341

9. Basu P., Nayak N.C, Archana (2007). -Foreign Direct Investmentin India: Emerging Horizonll, Indian Economic Review, Vol. XXXXII. No.2, pp. 255-266

10. Dr. Rashmi Sunil Dhobale "Advantages and disadvantages of FDI in India"ASM Group of institute of Pune, India , ISSN-2320-0065. Pp.428-437. 2015.

11. Dr. M. Madhavan and Mu.Nithyashree, "Make in India - Foreign Direct Investment and its Impact on Economic Growth" research revolution-international journal of social science and management volume -V, issue 3 ,December 2016 ISSN : 2319-300X

12. G.Patil, s., \& Dr.P.T.Chaudhari. (2014). Problems of Small Scale industries in India. international journal of Engneering and mangement Research, 19-21.

13. K.Narayanaswamyet.al" Make in India"49thIRF International Conference, 21st February 2016,Pune, India . ISBN : 978-93-85973-46-8

14. Matarneh, B. (2012). Working Capital management of small scale industries in Rajasthan. international jounal of fiancial research , 3 (2), 79-85.

15. Mohanty, G. (2018). Impact of FDI on small scale industry in india. journal of advances and scholarly Researches in allied Education , XV (1), 116-119.

16. Sangita G.Patil, Dr. P.T.Chaudhari "Problems of Small Scale Industries in India" International Journal of Engineering and Management Research, Volume-4, Issue-2, April-2014, ISSN No.: 2250-0758 pp no. 19-21. 